\title{
Tourism as Remembrance Activity: The International Gathering of Military Vehicles in a Post-Military Base in Poland
}

Dominika Czarnecka

DOI: 10.21104/CL.2019.4.03

\begin{abstract}
This article intends to explore the practices developed within the International Gathering of Military Vehicles "Caterpillars and Horseshoes" in Borne Sulinowo - a former military base in Poland. Focusing on this specific event, I attempt to demonstrate how tourism provides remembrance activities. Because all the practices mentioned in the text below have been established as a result of and in relation to the post-military base, it is also significant to examine how the tourist practices developed within the gathering are affected by the materiality of the site.
\end{abstract}

\section{Key words}

memorial, military object, Poland, post-military space, post-Soviet base, remembrance activity, tourism

\section{Acknowledgment}

I am grateful to the Institute of Archaeology and Ethnology of the Polish Academy of Sciences in Warsaw for supporting the research for this article partially.

\section{Contact}

Dominika Czarnecka, Ph.D., Institute of Archaeology and Ethnology, Polish Academy of Sciences, Al. Solidarności 105, 00-140 Warsaw, Poland; e-mail: d.czarnecka@hotmail.com.

\section{Jak citovat / How to cite}

Czarnecka, Dominika. (2019). Tourism as Remembrance Activity: The International Gathering of Military Vehicles in a Post-Military Base in Poland. Českýlid 106, 463-490. doi:http://dx.doi.org/10.21104/CL.2019.4.03 


\section{Introduction}

Research into sociocultural practices relating to tourism practices developed by civilians on the territories of former military zones in Central and Eastern Europe (CEE) is closely related to the analysis of sites of "difficult heritage" (Macdonald 2009), "negative heritage" (Meskell 2002) or "dissonant heritage" (Tunbridge - Ashworth 1995). Tourism activity provides potential opportunity for the development of local communities, as it facilitates dealing with the materiality of the sites, negotiating visions of the past upheld by various, often conflicted, communities of memory or acquiring knowledge which "[...] is constructed through encounters" (Crouch 2008: 207).

All practices inform the way people negotiate meanings (Crouch 2008: 212). Tourism practices understood as remembrance activities develop in places where memory of the past is still important. As the history of such places is often complicated, ambiguous and multidimensional, the places in question in relation to tourism take on the character of contested tourism spaces.

When analyzing social memory and tourism practices in places connected with World War I, Caroline Winter stated that tourism as remembrance activity may involve the practices of exploring by walking, and creating routes to traditional memorials such as battlefields, cemeteries or monuments. At the same time the researcher noticed that the 21st century has seen an increasingly intensive growth of new memorials - "[...] interactive museum displays and a wide range of formal, informal and community commemorations. [...] The new memorials of today, however, provide for interactive experiences for visitors which allow them to select information from a vast range of materials, which provides for the articulation of multiple and complex interpretations and memories." (Winter 2009: 621) The new memorials often take the form of grassroots initiatives of the local communities, which, on the one hand, involve entertainment and, on the other, have core functions related to remembrance, education, promotion of peace and so on. The emergence of new memorials reflects the fact that the articulation of social memories is beginning to take on new forms. It is worth adding that the traditional and new memorials are mutually related.

Adopting the above observations as the basis of further analysis, this article intends to examine practices developed within the International Gathering of Military Vehicles "Caterpillars and Horseshoes" (Gasienice $i$ Podkowy) in Borne Sulinowo - a former military base located in the north-western part of Poland, in the so-called "Recovered Territories".

1 "Recovered Territories" - territories in western Poland which used to belong to Germany until the end of World War II. In 1945 they were annexed to Poland by the resolutions of the Potsdam conference. 
Focusing on this specific event, I attempt to demonstrate how tourism provides remembrance activities, which are not ascribed to specific dates and give tourists more freedom to commemorate the past and develop techniques that are able to appeal to representatives of generations not personally or directly affected by the past events. All of the practices referred to in this article have been established as a result of and in relation to the post-military base. In consequence, it is also significant to address the question of the influence of the materiality of the site on tourist practices developed within the military gathering in Borne Sulinowo.

I draw upon empirical material on the tourism activity at the former military base in Borne Sulinowo. I conducted field research in February, May and August of 2015, in May 2016, and in August 2018. Each stay in Borne Sulinowo lasted between 7 and 10 days. Over this period I participated in two international gatherings of military vehicles: in August 2015 (12th Gathering) and in August 2018 (15th Gathering). Even though gatherings usually officially last three days, in practice many participants in these events stay in Borne Sulinowo at least a few days longer (usually between one and two weeks). Personally, I always arrived at the venue before the official opening of the gathering and stayed in the former military base a few days after it had ended. As a result, I was present during the final preparations for the event. Moreover, I had the opportunity to observe what was happening after the close of the official program of the gathering and listen to how both the participants and the inhabitants of Borne Sulinowo reflected and commented on it.

My research has generally and continuously been based on a qualitative, ethnographic approach. I have used various qualitative measures: semi-structured interviews (they have varied greatly in length, ranging from about one hour up to three hours, and all interviews have been recorded with an audio recorder), informal conversations, and participant observations. Data published on websites and discussions held on internet forums provided supplementary research material.

Semi-structured interviews were conducted with 15 persons (in some cases the same person was interviewed more than once). Three organizers of the event and inhabitants of Borne Sulinowo were interviewed (the participants' personal details were anonymized). In the case of the touristparticipants, data was obtained in the course of informal conversations and participant observation. Such methods of conducting field research were determined by the character of the military gatherings. Information obtained in this manner was analyzed and presented in this text in the form of consistent narrative, therefore the number of citations from conversations with tourist-participants is rather limited. 
This article is a part of a broader study in which I have been exploring the cultural practices developed in the post-Soviet military zones in CEE (see among others Demski - Czarnecka 2018; Seljamaa - Czarnecka Demski 2017; Demski - Czarnecka 2015; Czarnecka 2015).

\section{A General Outline of Tourism Activity in Post-Military Zones in Poland}

The development of tourism activity in post-military zones in Poland was initiated in the 1990s. This process was closely linked to global political and economic changes, as well as the socio-systemic transformation in Central and Eastern Europe after the fall of the Iron Curtain (1989). In the context of Soviet military bases in Poland the crucial event was the end of the withdrawal of the Russian Federation Army on September 18, 1993. ${ }^{2}$ Before that both the garrisons and territories in their direct neighborhood were under strict military supervision and inaccessible to civilians.

Traditionally, the post-military spaces are viewed as "barriers" for the development of tourism both due to political, functional (e.g. infrastructural deficits) and communication (peripheral character) reasons, as well as being associated with conflict, war, destruction and pollution. Paradoxically, however, the very same factors increasingly contribute to the growing attractiveness of post-military areas as tourist destinations. The unique built environment and cultural landscape of these areas affects the development of tourism within them, attracting, on the one hand, tourists fascinated by the unique qualities of the landscape, and on the other, those who are interested in visiting dark sites, which enables them to experience strong emotions, even though "intensities of darkness" vary from place to place (for more on dark tourism, see, for example, Foote 2003; Lennon - Foley 2000; Stone - Sharpley 2008). Tourist activities related to postmilitary zones are often collectively referred to as military tourism, dark tourism or "tourism of unwanted places" (Pokojska - Suszczewicz 2016). Whereas dark tourism and military tourism often refer to specific events that took place in the past, the notion of "tourism of unwanted places" demonstrates a much stronger connection to the present and contemporary attitude to so-called "difficult heritage".

Tourist activities related to post-military zones include, among others, military-themed attractions, natural attractions, or commemoration and remembrance attractions. This type of tourism is often associated with

2 Officially, 39 Soviet/Russian garrisons functioned in Poland from 1957. The majority of them were situated in the western part of the country. For more on this topic, see Czarnecka 2017: 123-125. 
authenticity ${ }^{3}$ and can be associated with educational and commemorating values, thus contributing to economic, social and cultural rehabilitation of the post-military spaces.

The transition of post-military zones into tourism sites depends on various cultural and socio-political factors (cf. Mansfeld - Korman 2015: 440). Even though many post-Soviet military bases on the territory of Central and Eastern Europe, including those in Poland, were abandoned and turned into ghost towns, ${ }^{4}$ which "may indicate a refusal, failure or inability to touristify the intimate relationship to the Soviet/Russian military past" (Seljamaa - Czarnecka - Demski 2017: 13; see also Demski 2017; Boldāne-Zelenkova 2017), the present analysis involves Borne Sulinowo, where tourist practices played a key role in the transformation, promotion and rehabilitation of the former military base.

\section{The International Gathering of Military Vehicles in Borne Sulinowo}

In 2015 Borne Sulinowo was inhabited by approximately 4900 people (Polska w liczbach - Borne Sulinowo). This former Soviet military base (1947-1992), which was previously a German one (1933-1945), is located $150 \mathrm{~km}$ in a straight line from the Polish-German border, surrounded by forests, close to Pile lake. The history of Borne Sulinowo and the events at the former military base following the withdrawal of the Russian Federa-

3 An analysis of the category of authenticity has not been assumed as part of the present study. An in-depth analysis of the authenticity of the site represented by the former military base would require a separate article. In this place I only wish to emphasize that authenticity cannot be understood as a fixed category and various ways of understanding authenticity have coexisted in reference to the described site (cf. Bruner 1994). The concept of authenticity remains vague. The assumption of the constructivist approach to authenticity (cf. Wang 1999) places the analysis of the case of the former military base between authenticity as a product feature and authenticity as an experience. The research I have conducted so far in Borne Sulinowo reveals that both the inhabitants of the former military base and tourists visiting the site are active agents who participate in the construction of authenticity in multiple ways (cf. Chronis - Hampton 2008).

4 In the post military spaces referred to as ghost towns (e.g. Pstrąże or Kłomino in western Poland) the tourism genre, referred to as the urban exploring movement, has been developing. Its aim is to preserve residential districts, undeveloped barracks or training ground fortifications in an unchanged form and to explore them in a non-invasive way. In consequence, urban exploration may be considered as remembrance activity: "Owing to explorers we can preserve memory of the heritage, especially the post-Soviet one which, as demonstrated earlier, is very prone to damage and liquidation" (Pokojska - Suszczewicz 2016: 112). 
tion soldiers (1992) and the transformation of Borne Sulinowo into a civilian town (1993) has been described in more detail in different articles, which I recommend for further reference as I wish to avoid unnecessary repetition (see among others Demski - Czarnecka 2015; Czarnecka 2015; Czarnecka 2017).

Soon after the civilian town was established both the local authorities and the new civilian settlers noticed the tourist potential of the former military base. It consisted of, on the one hand, its "untouched" nature, on the other, its complicated history, the atmosphere of mystery and special character of the post-military space. Among multiple practices gradually developed by civilian citizens of Borne Sulinowo (see Demski - Czarnecka 2018) tourist practices have played a key role in the place-making process.

The summer International Gathering of Military Vehicles "Caterpillars and Horseshoes" ${ }^{5}$ was first organized at the former military base in 2004. At present, the event attracts thousands of tourists to the town from Poland and abroad every year. The military gathering in Borne Sulinowo is not only the largest event of its type in Poland but is also one of the most recognized in Central and Eastern Europe. ${ }^{6}$ The dynamics of change in the process of development of the military gathering in Borne Sulinowo is demonstrated by the comment of one of its organizers:

We have been growing at an incredible pace, ... maybe not quite as much in the course of the last two or three years, it's not as intense. Maybe it has become more stabilized for now, as we have been limited here by space and our ability to handle ever more visitors and equipment. However, we are trying all the time to make it more attractive ... We are focusing on the quality, being professional, and trying not to be one-track minded, so I think that it has radically changed since the second or third gathering. It has been a different event since then

5 Since February 2012 winter gatherings of military vehicles have also been organized in Borne Sulinowo. These are on a much smaller scale - the 7th winter gathering in February 2018 attracted about one thousand participants (Borne Sulinowo. Duze zainteresowanie zimowym poligonem [Borne Sulinowo. High interest in the winter training grounds], February 4, 2018) and have not been included in this analysis.

6 The oldest Polish event of this type is the International Rally of Historical Military Vehicles in Darłowo, which has been taking place since June 1999 (Nagórski 2014). Military events organized on the territories of CEE countries include, among others, Tankové dni in Slovakian Trenčianske Stankovce or Retroměstečko Pardubice in the Czech Republic. 
... we are the biggest gathering. I am not being modest here, but that's what it looks like. (Fragment of an interview with the gathering organizer, Borne Sulinowo, May 2016.)

The first military gathering in Borne Sulinowo was a grassroots initiative of the town residents, without the support of the local authorities. Initially they used the International Rally of Historical Military Vehicles in Darłowo as a model. In 2005 they formed the Association of Friends of Borne Sulinowo Military History (http://www.zlot.bornesulinowo.pl/ strona/stowarzyszenie/), which soon took over the main responsibilities related to the organization of the event and its promotion. At present the summer military gathering is co-organized by the Centre of Culture and Recreation in Borne Sulinowo and the Borne Sulinowo municipality (the latter supports the organization predominantly in a financial manner). Numerous non-local institutions are involved in the organization of this event (among others, Museum of Polish Arms in Kołobrzeg, Polish Aero Club, Museum of Archeology and History in Stargard; the event has received the honorary patronage of, among others, the Voivod of Zachodniopomorskie and the Polish Army).

The name of the event corresponds with the names of military elements (caterpillars and horseshoes) used in the event logotype, which has been designed for promotional purposes. Apart from the the promotion of the event by local stakeholders during national and international tourist trade fairs, in brochures and on webpages, a significant contribution to disseminating information on the gathering throughout Poland was made by a nation-wide advertising campaign, which constituted part of the prize awarded to the event in 2010 - "Mocarz Gospodarczy Powiatu Szczecinieckiego w kategorii Pozagospodarcze Wydarzenie, Osobowość Roku, VII Międzynarodowy Zlot Pojazdów Militarnych 'Gąsienice i Podkowy' Borne Sulinowo 2010" (Economic Strongman of the Szczeciniecki Poviat in the category Non-economic Event, Personality of the Year for the 7th International Gathering of Military Vehicles "Caterpillars and Horseshoes" in Borne Sulinowo 2010):

I can't remember how many years ago it was when we won the prize of the marshal of the Zachodniopomorskie Voivodship for the best organized event. It included an advertising campaign in cities like Wrocław and Poznan with billboards promoting the gathering. Plenty of people came. (Fragment of an interview with the gathering organizer, Borne Sulinowo, May 2016.) 
For the period of the gathering the quiet town transforms into a lively center, whose streets are flooded with military vehicles with roaring engines and thousands of visitors wearing uniforms of foreign armies. The reports of the event's organizers regularly published on its official website (http://www.zlot.bornesulinowo.pl/letni/zloty/ii-zlot/; further referred to as MZPM) include annual descriptions, which are rather schematic:

It has only been eight years since the annual gathering of military enthusiasts was established, however, this event has become such a significant element in the town's landscape and rhythm that it is difficult to imagine Borne Sulinowo without it. For several days a year the military atmosphere of the past returns to the town, with the roaring of huge engines, the clanging of caterpillars and clouds of dust over the tankdrome. This year this warlike climate was complemented with planes flying above the town ... (8th Military Gathering, 2011.)

In the course of these few days a year, the color green - the symbol of our town - becomes the dominant element in the clothing of the majority of our inhabitants and tourists. ... For these few days the natural "decoration" of Borne Sulinowo - namely the space of the former training ground - becomes transformed into the largest Polish "camping". (7th Military Gathering, 2010.)

Interestingly enough, despite unquestionable promotional and economic success, the attitude of Borne Sulinowo residents to the military gathering, which affects the lives of all members of the local community, is not in complete accord:

The retired people do not always understand that the town with its many people needs a source of income, that there are enthusiasts... This is like harvest time... These fer days are a huge boost to the economy, the town becomes alive. (Fragment of an interview with the gathering organizer, Borne Sulinowo, February 2015.)

When it comes to the gathering, then it's more about presenting this territory, the fact that we have it. We also have history, but we base it on the territory and military machines, which come here, on uniforms, the sale of these uniforms, some weapons, some identity discs. I am not a fan of this gathering but I think it's good that it exists. I think it's one of the best events in Borne Sulinowo, because it attracts very many people and if it attracts very many people then shops sell goods, entrepreneurs have money and pay taxes, the local authorities receive 
money, and everything revolves around that. (Fragment of an interview with an inhabitant of Borne Sulinowo, February 2015.)

Even though some inhabitants cannot imagine Borne Sulinowo without the military gathering, others believe that the event has become "more boring" over time. In practice, though the basic formula of the gathering has remained unchanged, it is difficult not to notice new elements (for example, in 2017 [14th Gathering] parachuting shows were introduced for the first time, in 2018 [15th Gathering] a pyrotechnic and laser show took place for the first time, in the background of ruins of former military granary on the area of the former military training ground).

Additionally, the organizers of military gatherings have been involved in an argument with a group of Borne Sulinowo inhabitants, represented mostly by retirees, who wish to delegalize what they see as an "inconvenient" event. After the complaints filed in 2018, the President of the Association of Friends of Borne Sulinowo Military History published an appeal to the town inhabitants on its website:

With regard to complaints I have been receiving concerning inconveniences associated with International Gatherings of Military Vehicles in Borne Sulinowo, I wish to ask for your understanding and a broader perspective on this event. Annual gatherings are mass events organized not only for the sake of military enthusiasts but also in order to promote our town in Poland and, judging by the number of foreigners participating in the event, even abroad. There is most probably no single place in our country where the phrase "Borne Sulinow" does not evoke the association of "Gathering of Military Vehicles". ... All in all, despite inconveniences connected with traffic in the town, queues in shops, noise caused by evening artistic events, as a Borne Sulinowo fellow-resident I ask you for understanding and patience as well as to refrain from judgments based on "earned money", which we invest in the organization of the winter and summer gathering. (http://www.zlot.bornesulinowo.pl/strona/odezwa/, last accessed on October 28, 2018.)

Despite the discontent demonstrated by some, within just a few years the international military event has earned the status of an unconventional mass tourist event. One should add that the gathering encompasses a number of associated events such as dioramas, camps, contents, reenactments, concerts, purchasing replicas and souvenirs or eating food made in a military field kitchen (Figure 1). In effect, in many respects the event resembles a local "festival" or an "indulgence feast": 
We have more than 100 stands and wish to sell only products thematically related to the gathering. However, sometimes somebody calls us ... pays the fee, prepares their stand and it turns out that they sell plastic guns, balloons or something else... This shows that sometimes it becomes a kind of indulgence feast ... (Fragment of an interview with the gathering organizer, Borne Sulinowo, May 2016.)

Commodification is usually linked to the development of tourism. "Commodification refers to all the goods and services through which the sense of place can be accessed, both for insiders and outsiders. Commodification, as well as heritagization, operates within the framework of commemorating and forgetting. What is remembered usually comprises these elements which might interest people from the outside and, therefore, might 'sell' well." (Demski - Czarnecka 2018: 44) Apart from the trade stands situated within the area of the gathering, participants are offered paid excursions in military vehicles through the tankdrome as well as excursions around the entire former military base. Consequently, the built environment and the history of Borne Sulinowo have become transformed into an increasingly specialized tourist product, adhering to the requirements of the generation of today, for whom it is hard to imagine the meaning of a place in the absence of explicit information or visual evidence. Because meanings have been forgotten or access to them has been lost (though they have not disappeared), tourists may mistake the social and historic meaning of a site or fail to see it at all. As meanings are hidden in indiscernible details, tourists may feel estranged towards what they see (MacCannell 2005: 106). In this context we observe the increasing importance of the role of local tour guides and guiding (cf. Macdonald 2006), a range of people who are exploring the stories by themselves and, also, the sensory experience of a site.

\section{The Post-Military Base as a Contested Tourism Space}

Comments of the gathering's participants - both tourists and town residents - suggest that the key element determining the success and unique atmosphere of the event in Borne Sulinowo is the peculiar character of the post-military space marked by two major totalitarian regimes: fascism and communism. This is illustrated by, among others, the descriptions of the event published on its official website:

It is obvious that Borne Sulinowo is a perfect location for such an event and it would be difficult to imagine a better one. The former military base of the German and then Soviet Army, with the remnants 


\section{of massive warehouses, creates an unforgettable scenography. The} Gathering of Military Vehicles is simply ... in the right place here. (8th Military Gathering, 2011.)

The numerous military objects that had been left on the territory of the military base by soldiers of foreign armies were, in due course, damaged, stolen and appropriated for civilian use. Even so, since 1993 many postmilitary leftovers have been saved from destruction, renovated and displayed, including the original urban arrangement of the garrison, part of the barracks, fragments of the garrison walls, the military training ground and ruins of old granaries located on its territory, the cemetery of Soviet soldiers, and graves of prisoners of war of different nationalities. On the one hand, it is beyond any doubt that the development of tourism significantly affected the materiality of the site, on the other, however, the characteristics of the site (the way it was built, affected, developed) contributed to the process of transformation of the former military base into a popular and at the same time stand-alone tourism product (Figure 2). Moreover, in Borne Sulinowo, as in other post-Soviet bases "Inhabitants of former Soviet/Russian garrisons face the dilemma of how to renovate and modernize the built environment around them, while striving to preserve the original military features and aesthetics that attract tourists" (Seljamaa - Czarnecka - Demski 2017: 13).

In the context of the International Gathering of Military Vehicles it is the space of the entire former military base that plays a fundamental role as - though the actual event takes place on the territory of the former military training ground where the campsite and the tankdrome are located (Figure 3), along with the main stage for shows and contests, and commercial stands - in practice the activities of participants extend far beyond the military training ground: "Our guests have learned that the whole town is included in the party, the town becomes the party" (fragment of an interview with the gathering organizer, Borne Sulinowo, May 2016). As a result, on several August days tourists dressed in uniforms of foreign armies wander around the town and the neighboring territories of the post-Soviet base which are full of all kinds of military vehicles.

As with the landscape of battlefields or military zones, which emerge as a consequence of real or potential armed conflicts (see Sørensen - ViejoRose 2005), the landscape of the former military base can, according to Nicholas Saunders, be defined as a large scale military object (Saunders 2005: 83-84). Since the landscape of a former military base “ $\ldots$ is neither a single concept nor a solely-historical entity, but rather something political and dynamic, and always open for renegotiation" (Saunders 2005: 84), 
it can be gradually adjusted to the needs of tourist practices. Ultimately, it is through the demands of the tourist industry that the former military base becomes the product of "both local 'imaginings' and external tourist expectations" (Demski 2017: 181). The so-called adoption of military heritage $^{7}$ (both the post-Soviet and the post-German) by civilian residents of Borne Sulinowo facilitates not only the emphasizing and meeting of their needs and boosting the local economy, it also provides a way of preserving whatever was left behind by the users of the former military base, continuing the memory of the place.

Yet, the landscape of the former military base is a peculiar product in the context of tourist practices, its ambivalence combined with the power of attraction stems from its relations with past military conflicts: the actual ones (World Wars I and II), the potential one (the Cold War) and two major totalitarian regimes (fascism and communism).

\section{Remembrance Activities within the International Gathering of Military Vehicles in Borne Sulinowo}

In the 21st century the tourist industry significantly contributes to forming new events, created by grassroots initiatives of the local communities. These events, on the one hand involve entertainment, while on the other, they have core functions, which are remembrance, education or the promotion of peace - in a broader perspective they may be considered new memorials. Their potential consists in the possibility of providing access to information and negotiating meanings of the past to those who do not have personal experience related to it. The new memorials result more from an alternative experience of the past and different practices related to it, than is the case with traditional memorials. In contemporary culture, popular culture significantly affects the process of building a relationship with the past. Events like the International Gathering of Military Vehicles in Borne Sulinowo are a form of embodiment of those relations as well as the production, reproduction and articulation of social memory in a manner reflecting generational and experiential differences.

As rightly noted by Caroline Winter, "The social memory results from the activities of certain groups which establish agreement on which version of the past should be remembered ... The creation of social memory is a political process in which differing memories and forms of ar-

7 Heritage adoption - the adoption of material and non-material goods deriving from the past, when heritage, due to lack of legitimate heirs, is assumed by other successors along with all consequences of this fact (Kowalski 2013: 30). 
ticulation are negotiated through social groups" (Winter 2009: 614). The contemporary participants of the military gathering in Borne Sulinowo do not constitute a homogenous conglomerate as they differ significantly with respect to their needs, experiences, expectations and socio-cultural circumstances. The organizers, town inhabitants and tourists belong to different groups and communities of memory, and they play different social roles (soldiers, veterans, collectors, representatives of museums, reenactors, etc.), which undoubtedly affects their interpretations of the past, the military gathering and the former military base. With awareness of these differences, one should examine remembrance activities developed within the scope of the military gathering through the lens of the time and place in which they are created, realized and negotiated, which ultimately contributes to a more comprehensive recognition of the role of tourism in the process of memory- and place-making. The division suggested below is purely analytical. In practice, boundaries between particular categories are often blurred and functions of particular practices are complex.

Traditional Memorials, Practices of Creating Routes and Commemorating Values

As I have already mentioned, new and traditional memorials are usually mutually related as the emergence of new forms of memory articulation does not automatically result in the removal of the earlier ones, but rather contributes to broadening and diversifying the structure of forms and meanings. ${ }^{8}$ Such relations between new and traditional memorials may manifest themselves in numerous ways. For instance, on the one hand, many of the new memorials are established in near spatial proximity to traditional memorials. On the other hand, some of the traditional memorials are linked with specialized education and research centers or interactive exhibitions. Moreover, the new memorials in the form of events and activities may "include" traditional memorials by rebuilding walking trails

8 Apart from the gathering of military vehicles there appeared a different example demonstrating new forms of memory articulation which involved the plans of establishing a park of "unwanted" monuments in Borne Sulinowo (see more in Demski - Czarnecka 2018: 37-39). The project, announced by the Institute of National Remembrance in 2016 and finally not implemented, assumed that apart from founding an open-air museum (where disassembled Red Army monuments were to be placed) in the former military base a grand tourist, training and educational center would be established to provide, among others, scientific lectures, educational workshops for children and youth, multimedia exhibitions. 
around them and making visiting them an element of a more developed program of new events.

On the territory of the former military base social memory is articulated through traditional memorials such as stones, monuments, avenues, museum displays (see more in Demski - Czarnecka 2018), ceremonies performed in the town, as well as cemeteries (for more on cemeteries as sites of memory see Seaton 1996) and locations of World War I and II campsites for prisoners of war of different nationalities. Whilst monuments erected on the territory of former military base after 1993 enable the articulation of the memory of new settlers (former German and Soviet monuments have not been preserved - the Soviet soldiers destroyed the German monuments, and the Russians took nearly all the Soviet monuments with them when they left the base), cemeteries of prisoners of war and the cemetery of Soviet soldiers constitute significant sites of memory for different (not only local) communities of memory.

Moreover, for the former inhabitants of Borne Sulinowo and their successors - citizens of Germany and former Soviet Union - the entire military base is an "atypical" site of memory they visit during military gatherings, but not only then. "Physical places also hold and articulate memory" (Winter 2009: 611; see also Halbwachs 1992). They visit the town for purposes that are not primarily associated with leisure travel. A tour guide from Borne Sulinowo notices that:

Every year the number of visitors from Germany and Russia increases. Russians do not come for the gathering itself but because they want to meet at this exact location, those who used to live here, go to school here, or were born here. That's why they come specifically to the gathering. (Fragment of an interview with an inhabitant of Borne Sulinowo, May 2016.)

Old residents of the base are the former militaries and their families. However, the material I collected during field research suggests that of people who actually served in the army (citizens of different nationalities), both during World War II and in the postwar period, most usually participate in the event as observers and do not put on military uniforms:

However, these people, the ones who survived that period, not necessarily the war, but the postwar era, they are observers and not people who get involved in the games ... they come to see, they assess, watch, formulate some opinions but, actually, they do not reveal much about themselves. The majority of those who put on the uniforms 
have never had much in common with the whole thing. I don't say it's one hundred per cent, because many militaries appear as well ... but they wear historical uniforms so they represent a different era ... (Fragment of an interview with the gathering organizer, Borne Sulinowo, May 2016.)

In this case, then, the participation of former soldiers of different armies in military gatherings, combined with their conscious decision not to put on military uniforms, stands for a manifestation of a particular attitude towards the military past, a particular form of interpreting personal experience.

Apart from peculiar excursions of the former residents of Borne Sulinowo to the former military base, the practices of creating routes to the traditional memorials developed within the military gathering also take on much more conventional forms. They are often associated with commemorating values. During the military gathering visitors are offered paid rides around the former Soviet base with military vehicles (the tour program involves, among others, cemeteries of prisoners of war, bunkers, remnants of post-military buildings; "People come, there are these tours of the bunkers, they go with tour guides ... it's about the very fact of learning about the history of Borne" (fragment of an interview with an inhabitant of Borne Sulinowo, May 2016). Offers of this type include visits to memorial sites. The built environment "provides a material manifestation of absent histories and functions as a tangible medium that tourists can see, touch, feel and, as a result, connect with the narrative" (Chronis 2015: 136). Additionally, each year a group of light military vehicles travels to one of the neighboring towns. Selected participants of the gathering then participate in military events, which accompany the gathering in Borne Sulinowo but outside the territory of the former base, at the same time visiting sites of memory located along the route of the column of military vehicles. In 2017 (15th Gathering) a group of vehicles travelled to Czaplinek in order to take part in a military picnic organized by the town authorities. On the route the column stopped by the monument commemorating the death of the pilot officers of a SU-24 fighter jet in 1992 and the delegated group of the gathering participants laid a wreath at the monument. In 2015 (12th Gathering) the column travelled to military cemeteries in Borne Sulinowo and then went to a military picnic in Szczecinek. Similarly in 2014 (11th Gathering) a group of the gathering participants stopped at military cemeteries close to Krągi and in Szczecinek (MZPM).

Each military gathering ends with a huge, several-kilometer-long parade of military vehicles, whose official name is "Parade of the Blue Rib- 
bon of Lake Pile". Gathering participants proudly present their military vehicles driving through towns located around the lake and then triumphantly return to the territory of the former military training ground in Borne Sulinowo. The route of this drive-through remains the same. Every year the parade attracts crowds of visitors, including both tourists and residents of nearby towns. All of my interlocutors mentioned the parade in the context of the gathering and their remarks were only of a positive nature. Interestingly, some of them compared the parade and crowds watching it to their imagined visions of the arrival of the Soviet "liberators" in Poland at the end of World War II. It is beyond any doubt that in the case of post-war generations these imagined visions were significantly affected by popular culture (films, photos, books, songs). It is through this filter that the version of the past is articulated, which does not portray the reality of that period, but rather creates a peaceful and sanitized view of the past to provide entertainment for both insiders and outsiders.

\section{Educational Practices and Values}

Tourist practices understood as remembrance activities are often ascribed with an educational function. In reality, the majority of educational practices are closer to history than social memory, even though both of these categories pertain to the past and are mutually related (Connerton 1989; Nora 2004; Winter 2006). Apart from the cognitive and informative advantages, the educational function is often employed to legitimize specific actions and elevate the prestige of particular events. Such a strategy is not unfamiliar to the organizers of the International Gathering of Military Vehicles in Borne Sulinowo, who often refer to the gathering as a "history lesson":

Above all, we do not propagate anything, in any way, we are against that. But then this young man can see a living version of this history, in a more humorous perspective ... everybody is having fun here, there is no aggression, nobody actually shoots at anyone, not even in the reenactments. We try to imitate winning something, there are equipment and uniform demonstrations. There are no elements that would evoke any aggression ... (Fragment of an interview with the gathering organizer, Borne Sulinowo, May 2016.)

Also, the official website of the event features the following descriptions:

Apart from providing enthusiasts of militaries with the opportunity of meeting, the idea behind the Gathering of Military Vehicles in 
Borne Sulinowo is to educate broad social groups in history. This is achieved by reenactment groups and military museums. (14th Military Gathering, 2017.)

In reality, the remembrance activities of an educational quality that take place on the territory of former military training ground in Borne Sulinowo amount to something more than performances presented to the audience by reenactment groups ${ }^{9}$ or museum exhibitions (to mention only contests in military history or Polish history), however, the latter are undoubtedly the most institutionalized. During the event, military history (most often related to World War II, though not exclusively, as the military gathering is not dedicated to a single, specified historical period) is presented by national museums (e.g. Pilskie Military Museum) and private museums (e.g. Museum of Military History in Borne Sulinowo), military museums, and also those in which the history of military conflicts only represents an element of a larger entity (e.g. Regional Museum in Bydgoszcz).

During the military gathering, temporary exhibitions are established outdoors, under tents (Figure 4). Usually, their key element consists of military vehicles - medium scale military objects (Saunders 2005: 83-84) - that visitors can look into and take pictures of themselves next to them. Representatives of museum institutions answer visitors' questions, commonly focusing on the technical details of the equipment, promoting the units they represent and (re)producing specific narratives of the past. It is also sometimes the case that museums organize exhibitions during the gathering (for instance, in 2017, the Regional Museum in Bydgoszcz presented an exhibition illustrating the history of manufacturing explosives for the Third Reich during World War II, which was located in the former garrison bakery).

Interestingly, the exhibition strategy adopted by the gathering organizers has led to the creation of a complex and heterogeneous image of the military past, which involves various entities in the process of its (re) production, negotiation and articulation. As opposed to traditional museums, whose exhibition strategies are often based on a "monologue", the gathering features a "dialogue" between the representatives of museum institutions and visitors. Exhibitions created during the gathering are extremely temporary and based on military objects, which are "torn out" of museum collections they regularly belong to. If, in the two main types of museum exhibitions distinguished by Dean MacCannell - namely, collec-

9 For more on historical reenactments in Poland as a cultural phenomenon, see Baraniecka-Olszewska 2018. 
tions and representations - representation consists in placing the object in a certain reproduced situation designed as a whole (MacCannell 2005: 123), then it is precisely the process of creating representations that we are dealing with during this military gathering. Military objects that were in the past arbitrarily singled out from their original environment (meaning the primary context) and transferred to museums, during the gathering become exhibited in the environment, which is a copy of a certain comprehensive situation, assumed as significant from the point of view of what is being presented. Moreover, in this case, the key role is played not so much by other military objects but by the materiality of the site.

It would be an erroneous omission to limit the educational remembrance activities just to the institutional level. The need to educate society is also noticeable on the individual and non-institutionalized level. In the latter case, the significance of memories increases, which become materialized through practices and through environments that provide evocative stimuli (Hallam - Hockey 2001: 102). Many participants in the gathering, who bring their own vehicles and equipment for display, apart from testing and offering paid rides around the tankdrome, share their knowledge with the visitors (Figure 5). One of the event's participants, who paraded around the gathering in a Danish army uniform and posed for pictures with tourists, eagerly answering their questions, expressed it in the following words:

I have been coming here for years to educate people and popularize military knowledge. It is not important what type of educational activity one practices, but it matters that one educates people. I really appreciate everything that is authentic here, passionate people. However, I hate the commercialization and the fact that people offer me money for a picture with them. I am no pin-up boy, it's about the lessons of living history. (Fragment of an interview with a gathering participant, Borne Sulinowo, August 2015.)

It should also be emphasized that the knowledge and skills of civilians often surprise professional soldiers:

The majority of these soldiers, these officers are positively surprised by the whole thing. ... They are fascinated by the fact that a civilian who hasn't had anything to do with the army can possess equipment in such good condition as well as having such incredible knowledge. They frequently don't even try to hide the fact that military men can't match them. (Fragment of the interview with the gathering organizer, Borne Sulinowo, May 2016.) 
Though veterans and soldiers take part in the gathering, a remarkable part of the participants are ordinary people (for example, inhabitants of neighboring towns and tourists) who have never experienced war. Consequently, they interpret military history through their earlier experiences, personal values or perceptive abilities, which were shaped as a consequence of belonging to a particular community. These factors, alongside others, may result in the fact that some pieces of information are easily absorbed by the visitors while the others are blocked.

\section{Militarism, Peace and Ambivalence}

As I have already mentioned, both the organizers and participants of the military gathering in Borne Sulinowo emphasize that the entire event constitutes a peaceful "history lesson", which has nothing to do with promoting militarism. In their opinion, it is supposed to be fun and promote knowledge in the field of military history and understanding between generations, all of which is conducted in a "light-hearted" manner. Some of my interlocutors suggest that this approach is symbolized by a photograph taken during one of the gatherings, which later appeared on the Internet. The picture portrayed three "soldiers" wearing Polish, German and Russian uniforms, sitting under a tree, laughing and drinking beer. Commenting on this photo one of the gathering organizers stated "It's quite a distorted story, but these kids and teenagers take it lightheartedly" (fragment of an interview with the gathering organizer, Borne Sulinowo, May 2016). He also explained:

Many of these people who come here with military vehicles, have amazing knowledge and have never been in the army ... I think it's worth [showing] that this is a piece of history. If somebody has a different opinion, because of the German and Soviet uniforms, well, that was history, we have lived through it and we're not saying it was good or bad, we just want to show that something like this took place. (Fragment of an interview with the gathering organizer, Borne Sulinowo, May 2016.)

Indeed, the event proceeds in a peaceful and friendly atmosphere. Potential incidents, such as riots of neo-fascist groups, occur rarely and are followed by an immediate response by the organizers. Notably, many inhabitants of the town who survived World War II are against the gathering. Furthermore, those who actually served in the army and have personal experience related to war and the army very rarely put on military uniforms and get actively involved in the practices developed during the 
gathering. This distanced approach is sometimes justified by statements that the entire event is "just fun" and has nothing to do with the "real" war and military service. However, this is not the only justification. Among the inhabitants of Borne Sulinowo, particularly the residents of the local nursing home - people from the war generation - outrage is provoked, for instance, by the fact that the gathering participants parade around wearing the uniforms of the SS and the Red Army outside the area of the former military training ground:

Well, I will tell you honestly that I am horrified when I see people wearing German uniforms, especially those of the SS, walking around the town, especially Borne, because we have the nursing home, we have many people who remember those times and I'm sure it's not amusing for them. ... Actually, I had the opportunity to read a document which was formulated by residents of the local nursing home in which they said that they were a bit horrified by the fact that the participants are showing off with these uniforms and behaving as if, well, they are trying to somehow get a feel of the atmosphere of war. (Fragment of an interview with the gathering organizer, Borne Sulinowo, May 2016.)

In an interview for the local media one of the participants of the gathering stated:

There are many Germans among them who are not allowed to wear Nazi emblems publicly in their own country, while they can put them on in Poland, a country which experienced so much suffering because of them (cited in Wełnic 2018).

Ultimately, the gathering organizers changed the rules regulating the event in 2018. A principle was introduced specifying that uniforms of "hostile" formations can only be worn on the territory of the gathering and during reenactment performances. When leaving the gathering space it is necessary to change the uniform or cover the "controversial" emblems (Wełnic 2018).

This example illustrates that military objects used during the gathering are not only historical or museum objects but also carriers of memory, which activate memories on an individual and group level, with different communities of memory able to ascribe different, sometimes contradictory meanings to those objects. "Objects can be touchstones for the resonances of memory, past history, present circumstances, and future aspirations" (Kreamer 1992: 370-371). The individual and group knowledge of 
a portion of protesting residents in Borne Sulinowo is in conflict with some behaviors of the gathering's participants. For living witnesses of the past events rhetorical invocations of peace and also some of the tourist activities sit uneasily with the long history of military aggression. They can also overlook the suffering of victims.

Even though the idea of a military gathering is based on efforts intended to blur clear distinction between the ally and the enemy, the winner and the defeated, the event is also accompanied by other, less discernible tensions on an individual level. For instance, one of the gathering participants dressed as Taliban stated that he initially considered putting on the Red Army uniform. He explained that during World War II members of his family were killed both by German and Soviet soldiers, which is why, ultimately, he was unable to put on any of the uniforms. His conclusion was: "All in all, I am Polish!" (fragment of an interview with a gathering participant, Borne Sulinowo, August 2018).

Ultimately, in the context of remembrance activities developed during the gathering, what matters is not only memory being passed on within family circles and reproducing national narratives, but also values, meanings and experience, which the military objects represent in a particular time and place. Tourism practices developed during the gathering by means of producing particular relations with military objects strongly exploit the idea of technical advancement. This leads to a peculiar ambivalence as even though the direct reason for producing military objects was for use in armed conflicts (real and potential) and their basic function is connected with processes of destruction these facts have been completely omitted. Providing various technical details of military objects and presenting them in the context of particular stages of military technology production development disguises the fact that this very weaponry was used to kill people or destroy cities (cf. Czarnecka 2019; Raths 2013). As a result, this may lead to a certain idealization of military techniques and, at the same time, presenting military technology solely from the perspective of technological advancement may remove the questions of moral responsibility.

\section{Conclusion}

Among numerous tourist attractions systematically developed on the territory of the former military base after 1993, the summer International Gathering of Military Vehicles "Caterpillars and Horseshoes" within a period of several years, has gained the status of the largest and most recognized military event, both at the local and the national level. 
By focusing on a specific event I attempted to demonstrate how tourism provides remembrance activities not ascribed to strictly specified dates, thus providing tourists more freedom in commemorating the past and developing techniques that appeal to representatives of contemporary generations, who are deprived of personal experience and direct relationships with the past. Simultaneously, I tried to address the question of the impact of materiality of the site on tourism practices developed within the military gathering in Borne Sulinowo.

In many cases the specificity of post-military areas constitutes a "blockade" for the development of the tourism industry, which should not be surprising due to the fact that, even though the use of post-military spaces for tourism has been acknowledged, military bases were not designed to satisfy future tourists and their needs. Nonetheless, the military gathering in Borne Sulinowo probably would not have developed (at least, to that scale and that successfully) had it not been for the materiality of the site. The characteristics of the site (the way it was built, affected, developed) inspired civilian settlers to develop new practices, contributing to the process of transformation of the former military base into a popular and, at the same time, stand-alone tourism product.

In the case of Borne Sulinowo, the military gathering does not only serve the purpose of boosting the local economy, even though this element matters. Tourist practices developed within the gathering enable the preservation of whatever remained of past users of the former military base, thus continuing the memory of the place and, no less importantly, constituting a form of producing and articulating social memory of the military past in a lighthearted manner. Tourism as a remembrance activity contributes to "producing" new events - new memorials in a broader sense, which are exemplified by the military gathering in Borne Sulinowo. The new memorials are more a result of alternative experiences of the past and different practices related to it than is the case with traditional memorials. This type of practice does not involve "true" reconstructions of images of the past and recreating fallen "heroes", it is not about commemorating specific dates and events, but a form of "communion" with the past through objects and sensory experience of the site, all of which is then filtered through popular culture.

Similar practices may contribute to rehabilitating post-military spaces, helping them evolve from spaces of conflict into spaces of "dialogue". Nevertheless, remembrance activities provided by tourism at the same time make the ambivalence of post-military spaces increasingly marginalized. Primary meanings are more and more often becoming forgotten. 


\section{References:}

Baraniecka-Olszewska, Kamila. 2018. Reko-Rekonesans: Praktyka Autentyczności. Kęty: Wydawnictwo Marek Derewiecki.

Bruner, Edward. 1994. Abraham Lincoln as Authentic Reproduction. A Critique of Postmodernism. American Anthropologist 96, 2: 397-415. Boldāne-Zelenkova, Ilze. 2017. Mārciena - between Legacy and Nostalgia. Folklore. Electronic Fournal of Folklore 70: 149-170. DOI:10.7592/ FEJF2017.70.boldane_zelenkova

Chronis, Athinodoros. 2015. Moving Bodies and the Staging of the Tourist Experience. Annals of Tourism Research 55: 124-140. DOI:10.1016/j. annals.2015.09.008

Chronis, Athinodoros - Hampton, Ronald D. 2008. Consuming the Authentic Gettysburg: How a Tourist Landscape Becomes an Authentic Experience. Fournal of Consumer Behaviour 7: 111-126. DOI: 10.1002/ cb. 241

Connerton, Paul. 1989. How Societies Remember. Cambridge: Cambridge University Press.

Crouch, David. 2008. Surrounded by Place. Embodied Encounters. In: Coleman, Simon - Crang, Mike (eds.): Tourism. Between Place and Performance. New York, Oxford: Berghahn Books: 207-218.

Czarnecka, Dominika. 2015. Making Sense of the Past: (Re)constructing the Local Memorial Landscape in the Post-Soviet Base in Poland. Journal of Ethnology and Folkloristics 9, 2: 21-40; http://www.jef.ee/index.php/journal/article/view/204.

Czarnecka, Dominika. 2017. The 'Degraded' Landscape of a Post-Soviet Military Base in Poland: Outside Vs. Inside View. Folklore. Electronic Journal of Folklore 70: 121-148. DOI:10.7592/FEJF2017.70.czarnecka Czarnecka, Dominika. 2019. What Are Military Museums For? Polish, Romanian and Bulgarian Case Studies. Revue des Études Sud-Est Européennes 57: 39-50.

Demski, Dagnosław. 2017. Values, Substantiality, and Passage of Time: Representations and Reinterpretations of Military Heritage. Folklore. Electronic Fournal of Folklore 70: 171-192. DOI:10.7592/FEJF2017.70. demski

Demski, Dagnosław - Czarnecka, Dominika. 2015. Mapping Meanings in the Post-Soviet Landscape of Borne Sulinowo. Latvijas Vēstures Institūta Žurnāls: 2, 95: 96-120; https://www.lvi.lu.lv/lv/LVIZ_2015_ files/2numurs/D_Demski_D_Czarnecka_Mapping_LVIZ_2015_2.pdf. Demski, Dagnosław - Czarnecka, Dominika. 2018. A Site Shaped by Discontinuity: the Practices of Place-Making in a Post-Soviet Military 
Base in Poland. Suomen Antropologi. Fournal of the Finnish Anthropological Society 43, 2: 30-52. DOI:10.30676/jfas.v43i2.69843

Foote, Kenneth E. 2003. Shadowed ground: America's landscapes of voilence and tragedy. Austin: University of Texas.

Halbwachs, Maurice.1992. On Collective Memory. Chicago: University of Chicago Press.

Hallam, Elizabeth - Hockey, Jenny. 2001. Death, Memory and Material Culture. Oxford, New York: Berg.

Kowalski, Krzysztof. 2013. O istocie europejskiego dziedzictwa - rozważania. Kraków: Międzynarodowe Centrum Kultury.

Kreamer, Christine M. 1992. Defining Communities Through Exhibiting and Collecting. In: Karp, Ivan - Kreamer, Christine M. - Lavine, Steven D. (eds): Museums and Communities. Washington, London: Smithsonian Institution Press: 367-381.

Lennon, John - Foley, Malcolm. 2000. Dark Tourism: The Attraction of Death and Disaster. London: Continuum.

MacCannell, Dean. 2005. Turysta. Nowa teoria klasy próżniaczej. Warszawa: MUZA SA.

Macdonald, Sharon. 2006. Difficult Heritage: Negotiating the Nazi Past in Nuremberg and Beyond. Abington, New York: Routledge.

Mansfeld, Yoel - Korman, Tally. 2015. Between War and Peace: Conflict Heritage Tourism along Three Israeli Border Areas. Tourism Geographies. An International Fournal of Tourism Space, Place and Environment 17, 3: 437-460. DOI:10.1080/14616688.2015.1036916

Meskell, Lynn. 2002. Negative Heritage and Past Mastering in Archaeology. Anthropological Quarterly 75, 3: 557-574; https://www.jstor.org/ stable/3318204?seq=1\#page_scan_tab_contents.

Nora, Pierre. 2004. Between Memory and History. Les Lieux de Mémoire. In: Schwartz, Vanessa R. - Przybylski, Jeannene M. (eds.): The Nineteenth-Century Visual Culture Reader. New York, London: Routledge: 235-237.

Pokojska, Weronika - Suszczewicz, Michał. 2016. Turystyka miejsc niechcianych - poradzieckie garnizony w Polsce Zachodniej. Turystyka Kulturowa 2: 101-115.

Raths, Ralf. 2013. From Technical Showroom to Full-Fledged Museum: The German Tank Museum Munster. In: Muchitsch, Wolfgang (ed.): Does War Belongs to Musuems. Bielfield: Verlag: 83-91.

Saunders, Nicholas J. 2005. Culture, Conflict and Materiality: The Social Lives of Great War Objects. In: Finn, Bernard - Hacker, Barton C. (eds.): Materializing the Military. London: Science Museum: 77-94. Seaton, Anthony V. 1996. Guided by the Dark: From Thanatopsis to Thanatourism. Fournal of International Heritage Studies 22: 234-244. 
Seljamaa, Elo-Hanna - Czarnecka, Dominika - Demski, Dagnosław. 2017. "Small Places, Large Issues": Between Military Space and PostMilitary Place. Folklore. Electronic Fournal of Folklore 70: 7-18. DOI: 10.7592/FEJF2017.70.introduction

Sørensen, Marie Louise S. - Viejo-Rose, Dacia. 2005. War and Cultural Heritage: Biographies of Place. Cambridge: Cambridge University Press. Stone, Philip - Sharpley, Richard. 2008. Consuming dark tourism: A thanatological perspective. Annals of Tourism Research 35, 2: 574-595.

Tunbridge, John E. - Ashworth, Gregory J. 1995. Dissonant Heritage: The Management of the Past as a Resource in Conflict. Chichester, New York: John Wiley.

Wang, Ning. 1999. Rethinking Authenticity in Tourism Experience. Annals of Tourism Research 26, 2: 349-370.

Winter, Caroline. 2009. Tourism, Social Memory and the Great War. Annals of Tourism Research 36, 4: 607-626.

Winter, Jay. 2006. Remembering War: The Great War Between Memory and History in the Twentieth Century. New Haven: Yale University Press.

\section{Websites}

Borne Sulinowo. Duże zainteresowanie zimowym poligonem, February 4, 2018. [2018-10-13] Retrieved from: http://iszczecinek.pl/artykuly/aktualnosci/borne-sulinowo-duze-zainteresowanie-zimowym-poligonem-wideo. Międzynarodowy Zlot Pojazdów Militarnych "Gąsienice i Podkowy" Borne Sulinowo. [2018-10-26] Retrieved from: http://www.zlot.bornesulinowo.pl/letni/zloty/ii-zlot/.

Nagórski, Rafał. 2014. W Darłowie rozpoczął się XVII Międzynarodowy Zlot Historycznych Pojazdów Wojskowych, June 30, 2014, "Głos Koszaliński - GK24.pl". [2018-12-09] Retrieved from: https://gk24. $\mathrm{pl} / \mathrm{w}$-darlowie-rozpoczal-sie-xvii-miedzynarodowy-zlot-historycznych-pojazdow-wojskowych/ar/4614979.

Poligon Zimowy Borne Sulinowo. [2018-10-28] Retrieved from: http:// www.zlot.bornesulinowo.pl/zimowy/?page_id=9.

Polska w liczbach - Borne Sulinowo. [2015-12-28] Retrieved from: http://www.polskawliczbach.pl/Borne_Sulinowo.

Stowarzyszenie Miłośników Militarnej Historii Bornego Sulinowa. [2018-10-27] Retrieved from: http://www.zlot.bornesulinowo.pl/strona/stowarzyszenie/.

Wełnic, Rajmund 2018. Koniec zabarey w SS podczas zlotów w Bornem Sulinowie, portal GK24.pl. [2019-05-23] Retrieved from: https://gk24.pl/ koniec-zabawy-w-ss-podczas-zlotow-w-bornem-sulinowie/ar/12942706. 


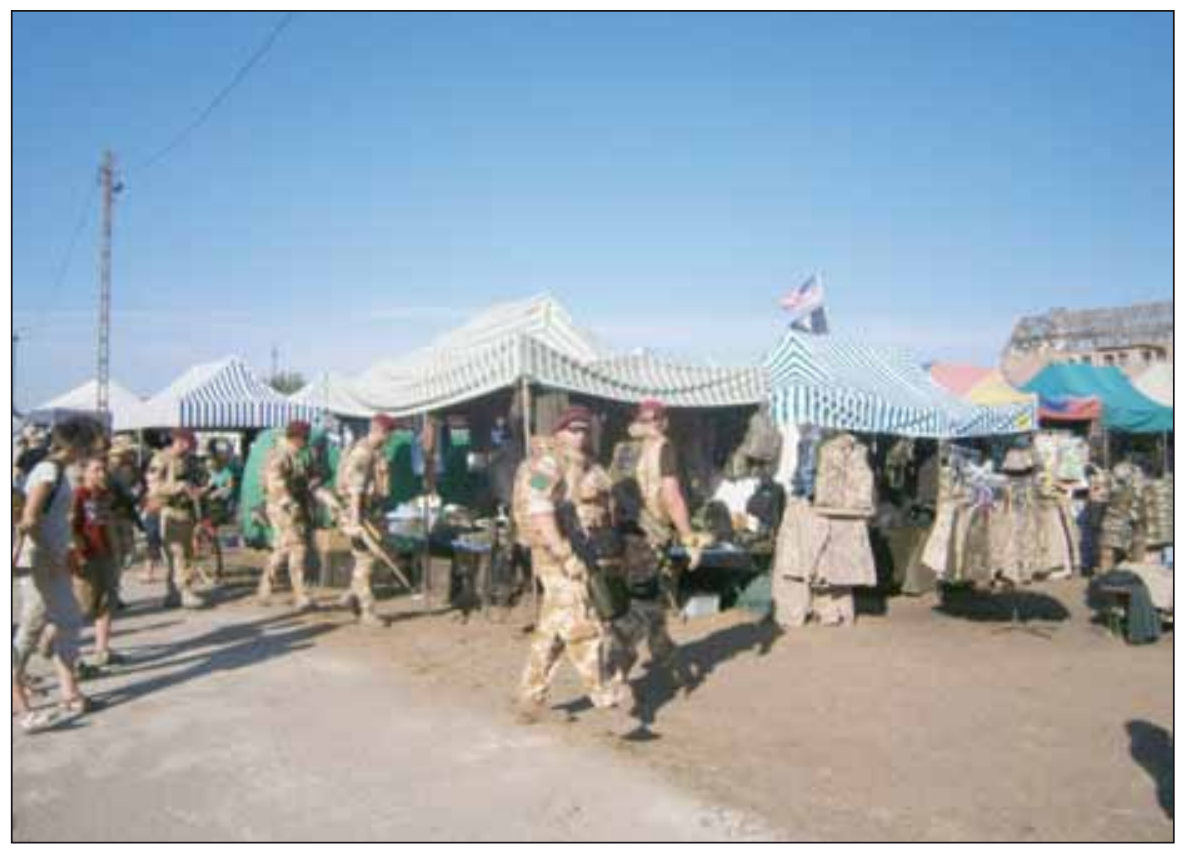

Figure 1 The trade stands situated within the territory of the military gathering (Source: author, 2015).

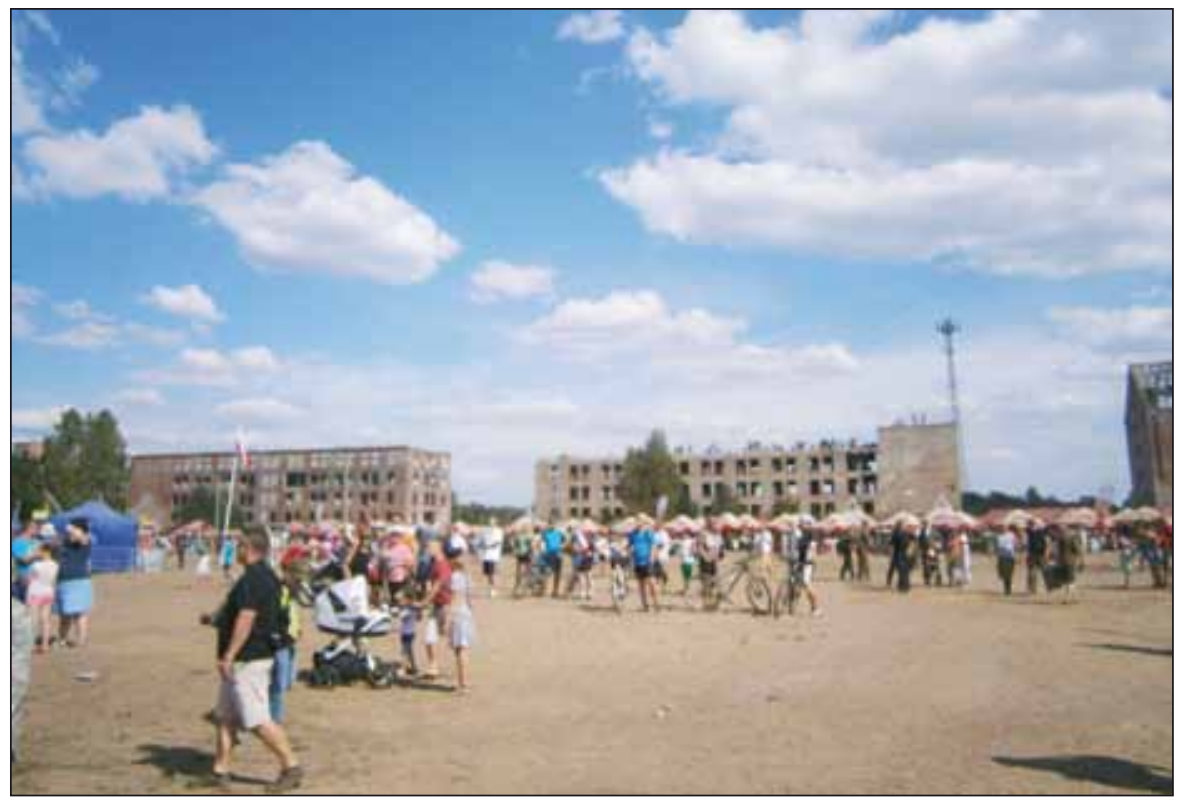

Figure 2 The military training ground and ruins of old granaries (Source: author, 2015). 


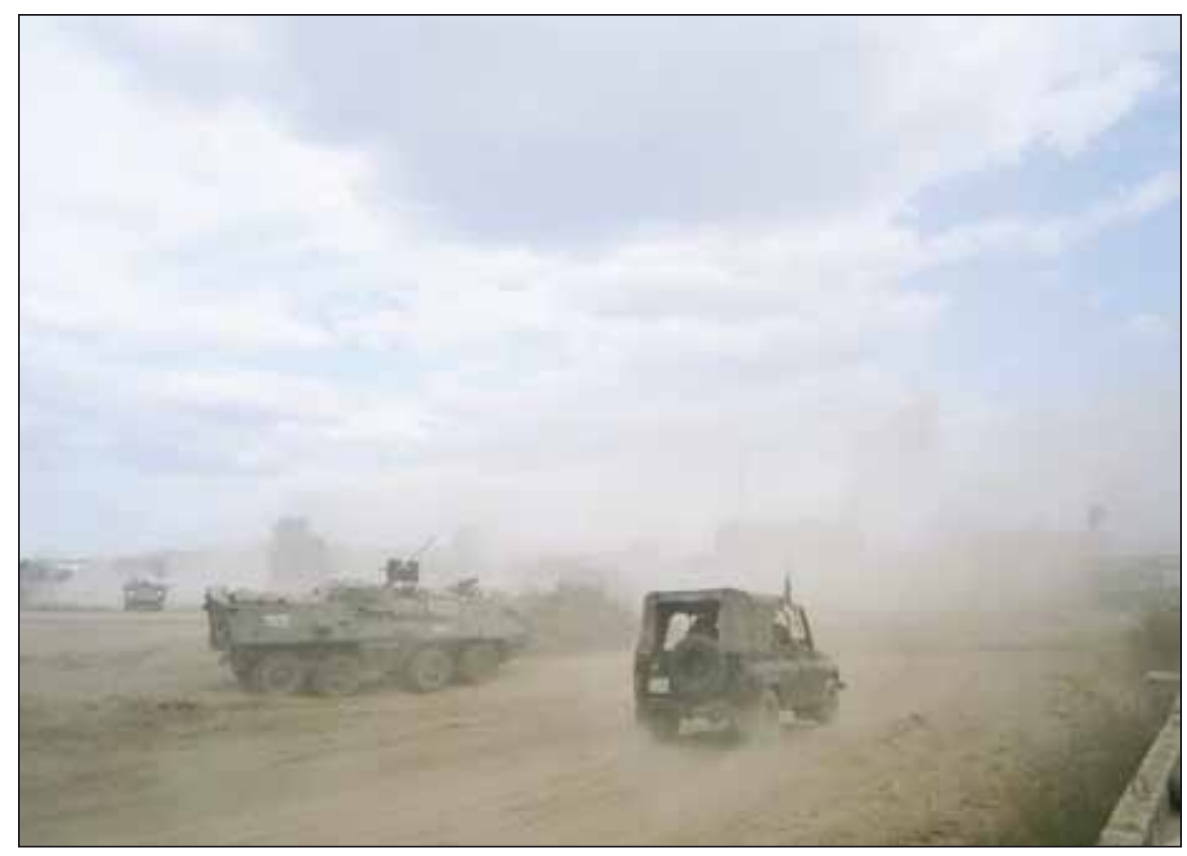

Figure 3 Rides around the tankdrome (Source: author, 2015).

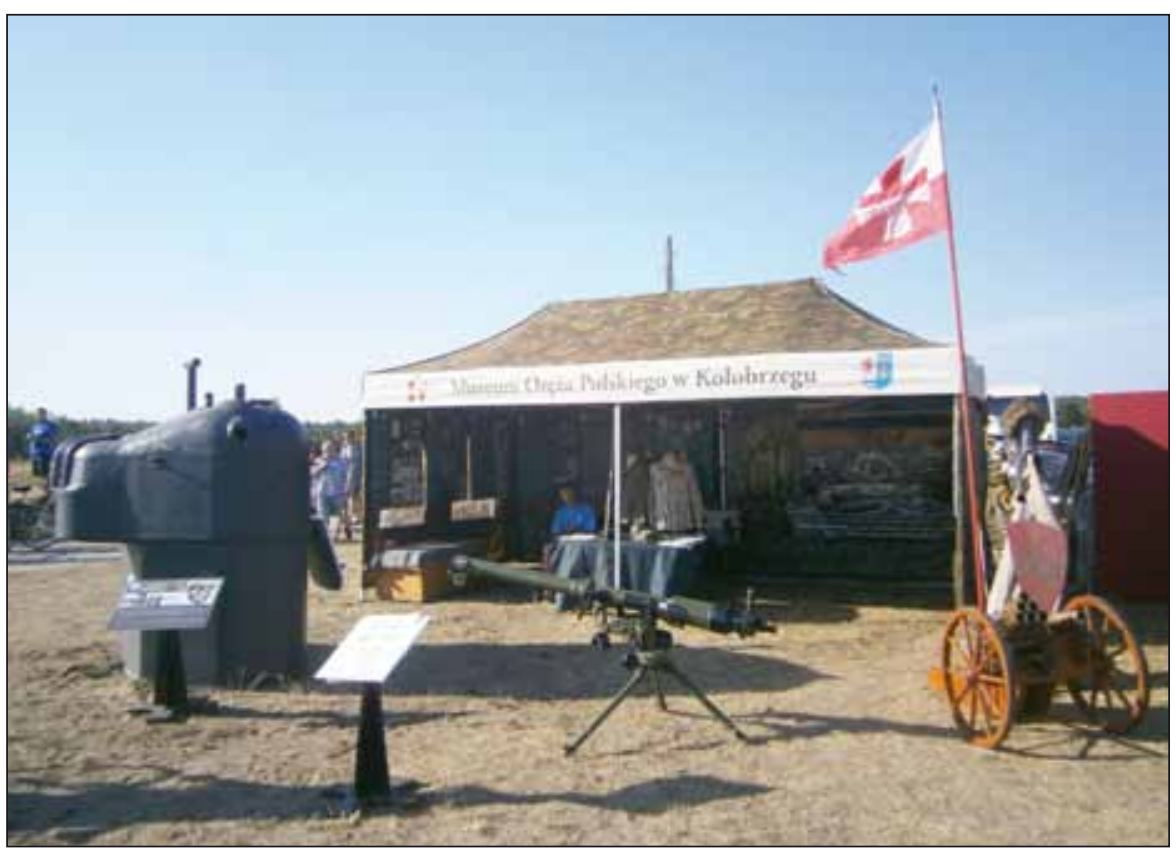

Figure 4 Museums under tents and temporary exhibitions (Source: author, 2015). 


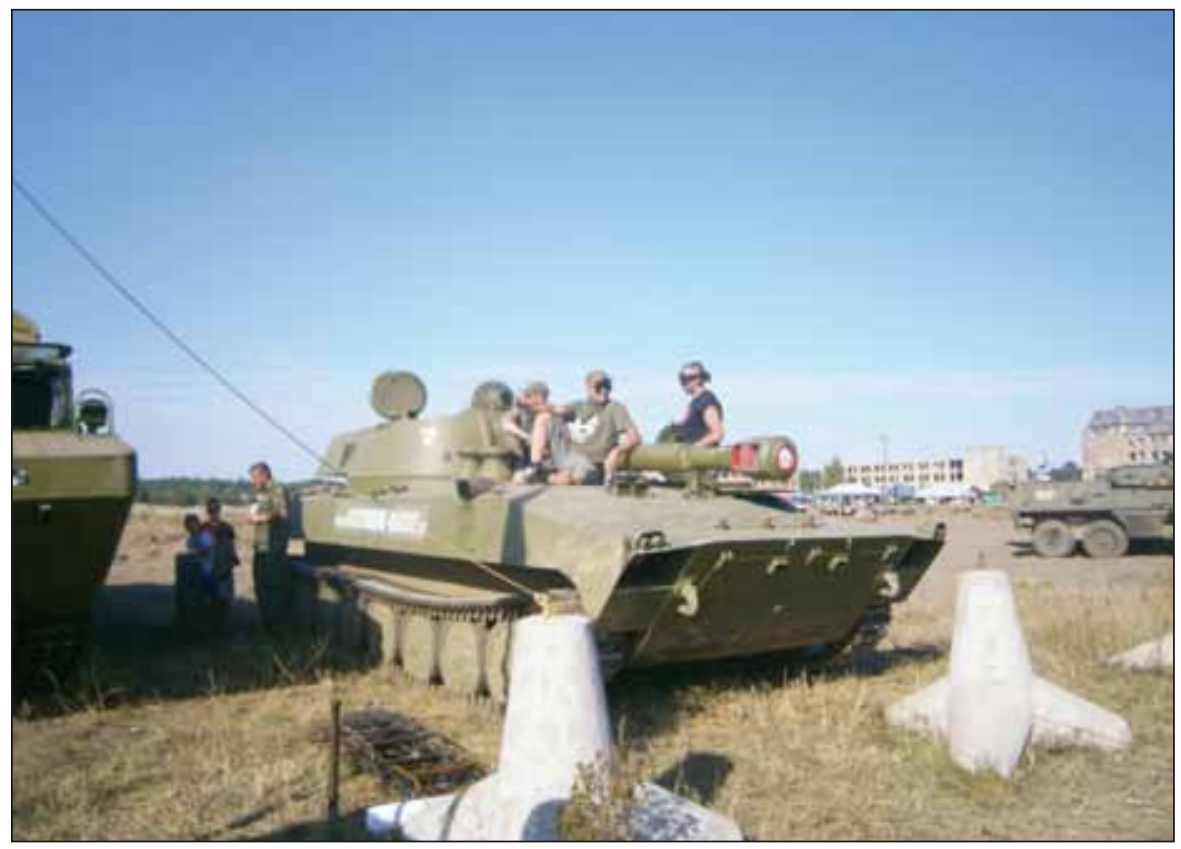

Figure 5 Offering paid rides around the tankdrome (Source: author, 2015). 